\title{
Impacts of community-based fish culture in seasonal floodplains on income, food security and employment in Bangladesh
}

\author{
A. B. M. Mahfuzul Haque ${ }^{1}$ - Madan Mohan Dey ${ }^{2}$
}

Received: 23 November 2015 / Accepted: 21 October 2016/Published online: 3 November 2016

(C) The Author(s) 2016. This article is published with open access at Springerlink.com

\begin{abstract}
This paper examines the impact of community based fish culture in seasonal floodplains on fish production, consumption, income, and food security of the participating households in Bangladesh. An analysis was performed using a randomly selected $46 \%$ of the households from the three project and control floodplains; data were collected using longitudinal surveys on a seasonally, quarterly and monthly basis for the years 2007, 2008 and 2009. Fish production, income and food security of the participating households was improved due to the adoption of an equitable and inclusive multi-stakeholder approach introduced by the project. Average fish production increased from $124 \mathrm{~kg} / \mathrm{ha} / \mathrm{yr}$. to 464 $\mathrm{kg} / \mathrm{ha} / \mathrm{yr}$. The introduced community-based fish culture approach generated 3.74 times more fish income for households in the project sites in comparison to the control sites. Per capita monthly fish consumption increased from $1.26 \mathrm{~kg}$ to $2.31 \mathrm{~kg}$ in the project sites, which was $32 \%$ higher than the control sites. Project implementation reduced the vulnerability of local beneficiaries, particularly of the landless and poor fishermen, by creating additional fishing opportunity for up to 6 months of the year. Promotion of the community based fish culture in seasonal floodplains may thus be useful in bringing about positive changes in the overall
\end{abstract}

\footnotetext{
A. B. M. Mahfuzul Haque

a.haque@cgiar.org

Madan Mohan Dey

mmd120@txstate.edu

1 Wageningen University, The Netherlands \& WorldFish-Bangladesh and South Asia, House 22B, Block-F, Road 7, Banani, Dhaka 1213, Bangladesh

2 Department of Agriculture, Texas State University, San Marcos, TX 78644, USA
}

floodplain productivity and livelihood gains for the poor people of Bangladesh.

Keywords Seasonal floodplain · Fish culture · Multi stakeholder approach · Food security and livelihood

\section{Introduction}

Water is a highly demanded natural resource and a key agricultural input (Grafton et al. 2015; Huang et al. 2015). How water is used is critical for sustainable agricultural intensification and increase of food availability (Grafton et al. 2015). However, strategies for increasing agricultural productivity have been mainly concentrated on crop cultivation (see, for example, Wichelns 2015). Culture of fish in seasonal floodplains can be an important tool for sustainably improving agricultural and floodplain productivity and for strengthening rural economies (Rahman et al. 1999; Dey et al. 2005a; Dey and Prein 2006; Nagabhatla et al. 2012).

The Indo-Gangetic Basin of Bangladesh has a large number of seasonal floodplains that offer great opportunities for the promotion of fish culture to benefit the poor. Bangladesh has rich freshwater resources, and therefore has a huge potential for fisheries development. ${ }^{1}$ There are 4.69 million ha of inland waters, $58 \%$ of which are floodplains (FRSS 2015).

\footnotetext{
${ }^{1}$ Fisheries are a key subsector and significant contributor to the national economy of Bangladesh; they contribute $4.37 \%$ to the national GDP and almost one-fourth $(23.37 \%)$ to the agricultural GDP of Bangladesh (Bangladesh Economic Review 2013). The country's export earnings from the fisheries sector was $2.01 \%$ in 2012-2013, and the total national fish production was 3.41 million tons (DoF 2013). Of the total fish production, inland open waters, inland closed waters, and marine fisheries contributed respectively $28.19 \%, 54.54 \%$, and $17.27 \%$ (DoF 2013). Bangladesh is now the fourth largest aquaculture fish producer in the world (FAO 2014).
} 
During monsoons, almost half of the country is inundated, and these areas are reported as floodplains. In most cases, these floodplains are used for the production of fish and other aquatic animals and plants, which have a large impact on the livelihoods of many people, including poor fishermen. About 6.7 million people receive direct benefits to their food security and livelihoods from the floodplains in Bangladesh, of which 2.7 million are classified as poor or extremely poor (WorldFish Center 2005; Dey et al. 2005b; Dey and Prein 2005; Dey and Prein 2006; DoF 2013).

Historically, floodplains were the major source of natural fish production, but currently, fish catches are declining. Yields of typical capture fisheries activity usually range from 150 to $350 \mathrm{~kg} / \mathrm{ha}$ (WorldFish 2007). However, open access to these resources and their indiscriminate use have led to overexploitation and reduced productivity, making the system very unreliable in its ability to generate benefits for the people. There is potential for using these floodplains for fish culture by building enclosures in parts of the floodwater, and stocking fingerlings in addition to the non-stocked fish (see, for example, Dey et al. 2005a). If properly managed, these water resources could play a pivotal role in boosting fish production, generating income, and creating employment opportunities. Recent evidence from Daudkandi in the Comilla district of Bangladesh, where floodplains under private ownerships were transformed to fish culture using semi-intensive management, show that fish culture in floodplains can results in very high fish production levels (up to $3000 \mathrm{~kg} \cdot \mathrm{ha}^{-1}$ ) and income, but there is a need for concerted efforts to include the poor as direct beneficiaries (Toufique and Gregory 2008).

In recent years, the WorldFish Center (WorldFish) established a new approach, known as community based fish culture (CBFC), where fish are cultured communally during the flood season but the same land is cultivated individually to rice during the dry season (Dey and Prein 2005; Dey et al. 2005a). This approach ${ }^{2}$ integrates biological research on rice and fish with institutional research on common property resource governance. Field trials of this concept in Bangladesh and Vietnam during 1998 to 2000 demonstrated the feasibility of community based fish culture in seasonal floodplains (Dey et al. 2005a). During 2005 to 2010, WorldFish and its research partners implemented a follow-up project entitled "Community-based Fish Culture in Seasonal Floodplains and Irrigation Systems", to test the CBFC concept in Bangladesh, Cambodia, China, Vietnam and Mali under different socio-cultural and institutional environments.

The adoption of fish culture technology in pond or floodplain systems can contribute to improved food security and nutrition for poor households in several ways; i) generating income from fish culture, ii) creating alternative employment

\footnotetext{
${ }^{2}$ Readers are referred to Dey and Prein (2005) and Dey et al. (2005a, 2005b) for detailed discussion of the CBFC approach.
}

generating activities and increasing labour productivity, and iii) increasing available food supply and fish consumption (Edwards 1999; Ahmed and Lorica 2002; Jahan et al. 2010). This paper examines the multi-dimensional impact of CBFC in seasonal floodplains at both household level and community level, based on data collected under the "Communitybased Fish Culture in Seasonal Floodplains and Irrigation System" project in Bangladesh.

This study used household and community level data, collected using qualitative as well as quantitative methods in examining the impact of community based fish culture (CBFC) in seasonal floodplains on food security, income, and employment of the participants; starting with a conceptual framework on how positive impacts take effect. The conceptual framework is presented in Fig. 1, showing management strategies of community based fish culture in seasonal floodplains and identifying direct and indirect effects at household and community levels. In this project we considered the floodplain as a community of interest, because the people of the surrounding villages have a shared interest in enhancing fish production from the seasonally flooded areas by using a collective approach to fish culture.

The study looked at the overall hypothesis that CBFC leads to improved floodplain productivity. First, CBFC management directly improves the natural resource capital (soil and water), increases fish production, makes possible multiple uses of the floodplain waters, increases household income and increases fish consumption. Secondly, CBFC management creates employment, ensures property rights, market access, strengthens local level institutions, and improves human and social capital i.e. trust and cooperation.

The paper comprises five sections; following this introduction, section two provides an overview of the "Community-based Fish Culture in Seasonal Floodplains and Irrigation Systems" project in Bangladesh. Section three outlines the methods, data collection, and analytical techniques used. Section four explains the economic impact of CBFC at floodplain level as well as the household level with respect to income, employment, and fish consumption. Conclusions and policy implications are discussed in the final section.

\section{"Community-based fish culture in seasonal floodplains and irrigation systems" project in Bangladesh}

\section{Project implementing agencies}

The Project was jointly implemented by the Bangladesh and South Asia Office of WorldFish, the Bangladesh Agricultural Research Council (BARC) and the Department of Fisheries (DoF) from 2005 to 2010. Their major activities 
Fig. 1 Conceptual model for impact assessment. Adapted from Dey et al. (2007) and Ahmed and Lorica (2002)

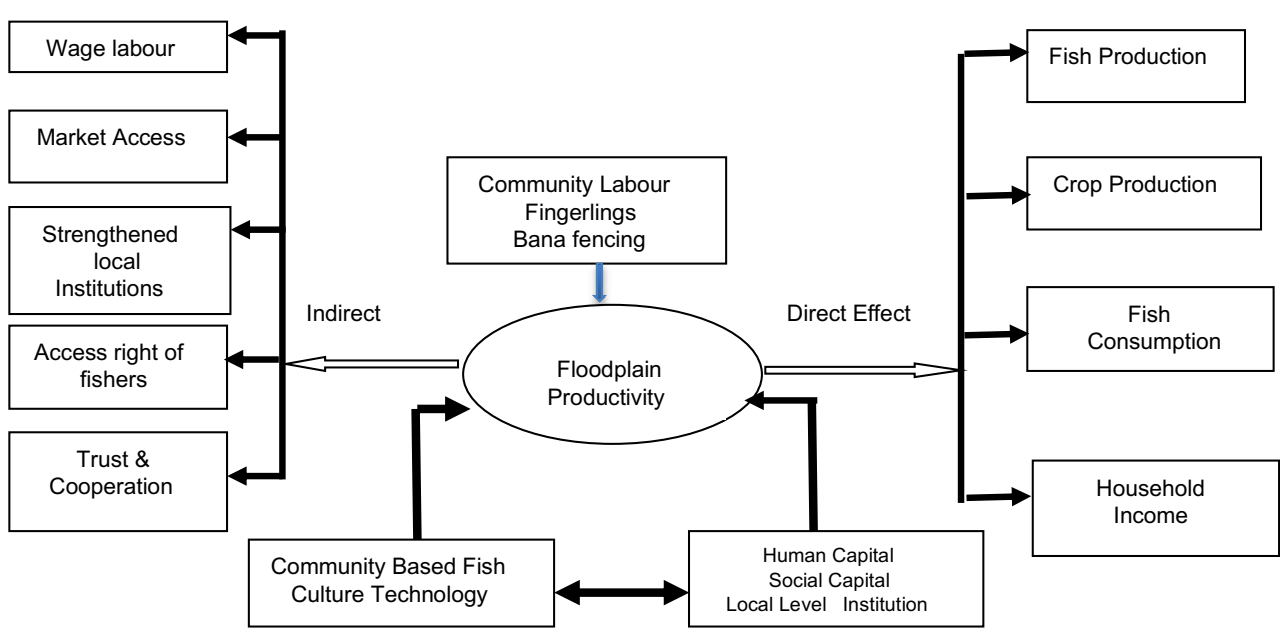

were as follows: WorldFish had overall responsibility for the implementation of the project; it provided all necessary technical assistance, support services to researchers and carried out all project management activities. BARC provided national project leadership and played a crucial role in forging close relationships with DoF and WorldFish, and conducted the coordination, monitoring and evaluation of project activities. DoF played a role in the selection of the project sites, in the establishment of community based organizations and the implementation of the overall project activities.

\section{Description of study locations}

Six floodplains in three different river basins of Bangladesh were selected for this study. These floodplains are located in the Brahamaputra, Padma and Teesta river basins in Mymensingh, Rajshahi and Rangpur districts, respectively. One project site and a comparable control site with similar agro-ecological and socio-economic characteristics were selected from each floodplain. The selected floodplains were under two types of land ownership category: public-private and private. Public floodplains are open access areas during the monsoon season when all land is inundated. Access to private floodplains, on the other hand, then remains in control of the landowners. Characteristics of the selected floodplains are shown in Table 1. In private land, the dominant farming system before the intervention was the single-crop, irrigated 'boro' rice during the dry season (January to May). At all six sites (project and control), prior to the project intervention, capture fisheries were the main livelihood activity during the rainy season (June to November). Topographically, these areas are almost enclosed by natural elevated lands, raised homesteads, dams for roads, train tracks, canals etc. It is possible to close off the open sides with a fence, and stock the enclosed waterbody with fish during the rainy season.

\section{Technical intervention}

The technological intervention followed in the project had two main components: a) construction of enclosures for fish culture in the flood season, and b) stocking of fingerling and fish culture during the flood season. Enclosures were constructed
Table 1 Characteristics of the selected floodplains

\begin{tabular}{llll}
\hline Name of floodplains & Area(ha) & Ownership & River Basin \\
\hline Project sites: & & & \\
Beel Mail & 40 (public 15.2 ha, Private 24.8 ha) & Public \& private & Padma \\
Kalmina Beel & 33 & Private & Brahmaputra \\
Angrar Beel & 31 & Private & Teesta \\
Control sites: & & & \\
Chandpur Beel & 50 (public 12.8 ha, Private 37.2 ha) & Public \& private & Padma \\
Andola Beel & 16 & Private & Brahmaputra \\
Paingler Beel & 20 & Private & Teesta \\
\hline
\end{tabular}

Beel is a local term for low-lying agricultural land with static water mostly created due to inundation by floodwater or rains 
to manage the inflow and outflow of water, regulate water retention, and prevent escape of stocked fingerlings. Bamboo fences (locally known as bana) were installed at the inlets and outlets, permitting the entry of larvae and hatchlings of small indigenous species and preventing stocked fish from escaping (Rahman et al. 2010a). In some cases, the peripheral dikes of the water bodies were raised for holding water as well as preventing the escape of stocked fish. In Kalmina beel, several concrete circular culverts were installed at inflow and outflow points to maintain water levels.

In the project sites, alternating fish-rice culture (fish culture during the rainy season and boro rice culture during the dry season) was followed. Fingerlings were stocked, and both naturally recruited (non-stocked) and stocked fish were cultured during the rainy season through a group approach. Farmers continued to cultivate rice individually in their respective lands during the dry season. The species combinations, ratios and stocking densities of fish fingerlings were determined based on factors such as local availability of fingerlings, the growth rates of the fish species and the experience of project participants. Indian major carps (Rohu, Catla and Mrigal) and exotic carps (Silver Carp, Common Carp) were selected and stocked in the seasonal floodplains at varying ratios and stocking densities. Fingerlings were procured either from the nursery farms of the beneficiaries or from nearby commercial nursery farms. Harvesting of fish was started 4 months after stocking and continued up to 6 months. In some cases, fish were harvested over 2-3 months as decided by the beneficiaries. Harvests of stocked and non-stocked fish from the floodplains were recorded and used for sale and for household consumption.

\section{Institutional arrangement}

A community-based approach was followed in all the project sites for fish culture during the rainy season. This approach is necessary as individual plots are not discernible when flooded whereas they are clearly discernible and respected in the dry season. In each of three project sites, Floodplain Management Committees (FMC) were formed in a participatory way representing all stakeholders who had access and control over the resources, such as wealthy landowners, landowning fishers, and landless, poor fishers. The FMCs consisted of 15-20 members, including a president, vice-president, secretary, and cashier. They were tasked to solve conflicts and ensure that benefits were distributed among the beneficiaries. Local project implementation committees (PICs) were formed with representatives from DoF, WorldFish, other related government departments, and the president and the secretary of the FMCs. PIC's responsibilities were overall supervision and monitoring of project sites, encouragement of co-management and establishment of working rules for better managing floodplains under community-based fish culture, together with the empowerment of the poorer fishers.

\section{Data and methods}

\section{Data}

Many studies have failed to establish a counterfactual when conducting before-and-after analysis to assess the impact of a new technology on income, food security, etc. (Adato and Meinzen-Dick 2007). In order to avoid the counterfactual situation, we have considered introducing community based fish culture technology with a baseline and panel data and also compared before-and-after scenarios in the selected sites and households, both with and without adoption of the technology.

This paper used data collected ${ }^{3}$ from six floodplains in Bangladesh, of which three were CBFC project areas and three were control sites. It is important to mention that these control floodplains were chosen in such a way so that the socioeconomic and environmental conditions were similar to the CBFC project floodplains. DoF officials and researchers who were involved in this project visited the proposed sites several times in order to identify the target populations. Several meetings were organized with the local people and households which mainly depended on floodplains for their income were selected as project members and included in the community management project. Control households were selected in the same way.

The project officially started in 2005 and floodplains were selected in 2006. Project staff conducted a baseline survey in 2006 in project and control areas, which covered the floodplains used for fishing, rice production, and some additional household socio-economic data. A range of qualitative and quantitative techniques coupled with community profiles, participatory resource mapping, field observations, semi-structured interviews with key informants, and Focus Group Discussions were applied for collecting baseline information.

Building on the baseline survey, a stratified random sampling procedure was followed to select the households for the monitoring of various parameters. The strata identified were professional or full-time fishers, landless seasonal fishers, and landowners. Sixty samples from each floodplain were selected annually for this study: 180 samples from project floodplains and 180 samples from control floodplains. Out of the total population of 778

\footnotetext{
${ }^{3}$ The first author was directly involved in collecting these data. The second author initiated and led the implementation of this multi-country project during its initial phase.
} 
households in six project and control areas, about $46 \%$ of the households were selected. Data were collected using longitudinal surveys on a quarterly, seasonal (six monthly) and monthly basis. Information on earnings and expenditure were collected on a quarterly basis, data on crop production and input use were collected at six monthly intervals, and fish consumption data were collected on a monthly basis. Three years $(2007,2008$ and 2009) worth of panel data were used for this analysis.

This paper aimed to describe a before-and-after analysis on the intervention and without an intervention design, but it was not possible for all indicators. Before-and-after and project-control comparisons were simultaneously followed depending on the availability of data. Before and after analysis was used when the data were available and compatible, while a with-and-without intervention analysis was made to monitor the changes and to analyze the impact of CBFC. All surveys were designed and managed using a relational access database.

Data collected were tabulated and analyzed in accordance with the objectives of the study. Descriptive statistics and a cost and return analysis of the selected floodplains were made. At the level of the beneficiaries, descriptive analysis was also conducted for the consumption data. However, for the income data of the beneficiaries, a random effect model of panel data was run. Having established that the random effects model is a better fit, a quantitative random effects model was developed to estimate the impact of participating in the program on fish production and household income. Before the model estimation, a propensity score matching (PSM) method was employed to make comparisons between program participants and the control group.

\section{Model for estimation}

We employed a random effects model of panel data to estimate the impact of participation in the CBFC program on fish income as well as household income. However, we first tested whether the fixed or random effects model was more appropriate for this dataset using the Hausman test ${ }^{4}$ indicating that the random effects model provided a better fit. This is possibly because some of the variables, such as education level of the head of the household, farm size, ditch area, etc., were time invariant; which indicates that the householdlevel independent variables $\left(\mathrm{X}_{\mathrm{it}}\right)$ are uncorrelated with the individual effects $\left(\alpha_{i}\right)$. Therefore, in this case, the random effects model is better. It is important to mention, that the propensity score matching (PSM) method was employed initially to make comparisons between program participants and the control group. Afterwards the random effects model was estimated with common support. This ensures the exclusion of control observations that are not "nearby" to the propensity score distribution of the project observations.

The specification is as follows:

$\mathrm{y}_{\mathrm{it}}=\beta_{0}+\beta \mathrm{x}_{i t}^{\prime}+\alpha_{i}+\varepsilon_{\mathrm{it}}$, where $\varepsilon_{\mathrm{it}} \sim \operatorname{IID}\left(0, \sigma_{\varepsilon}^{2}\right)$ and $\alpha_{\mathrm{i}} \sim \operatorname{IID}\left(0, \sigma_{\alpha}^{2}\right)$.

The empirical model is then:

$y_{\text {it }}=\beta_{0}+\beta_{1}$ participation $_{\text {it }}+\beta_{2}$ age $_{\text {it }}+\beta_{3}$ education $_{\text {it }}+\beta_{4}$ religion $_{\text {it }}+\beta_{5}$ familysize $_{\text {it }}+\beta_{6}$ rice land $_{\text {it }}+$ $\beta_{7}$ household pond $_{\text {it }}+\beta_{8}$ boat $_{\text {it }}+\beta_{9}$ ditch area $_{\text {it }}+\sum \gamma_{\mathrm{t}}$ year $_{\mathrm{t}}+\alpha_{\mathrm{i}}+\varepsilon_{\mathrm{it}}$.

Where, $\mathrm{y}=$ income per household (USD), and various explanatory variables include participation in CBFC (' 1 ' participating, ' 0 ' otherwise), age (years), education (years of schooling), religion (' 1 ' hindu, ' 0 ' otherwise), family size (number), rice land (hectare/household), household pond (hectare), boat (number), and ditch area (hectare/household).

$\alpha_{\mathrm{i}}+\varepsilon_{\mathrm{it}}$ is treated as an error term consisting of two components: an individual-specific component, which does not vary over time, and a remainder component, which is assumed to be uncorrelated over time.

\section{Result and discussion}

\section{Direct impact of community-based fish culture}

Impact on fish production at floodplain level

The three control sites of Chandur Beel (public-private floodplain), Andola Beel (private floodplain), and Paingler Beel

\footnotetext{
${ }^{4}$ In the Hausman test, $\mathrm{H}_{0}$ (the difference in coefficients) was not systematic: $\chi^{2}(7)=2.44$ and prob. $>\chi^{2}=0.9314$.
} 
Fig. 2 Fish production in the three sites within the project area before (i.e. the year 2006) and after implementation of the $\mathrm{CBFC}$ system

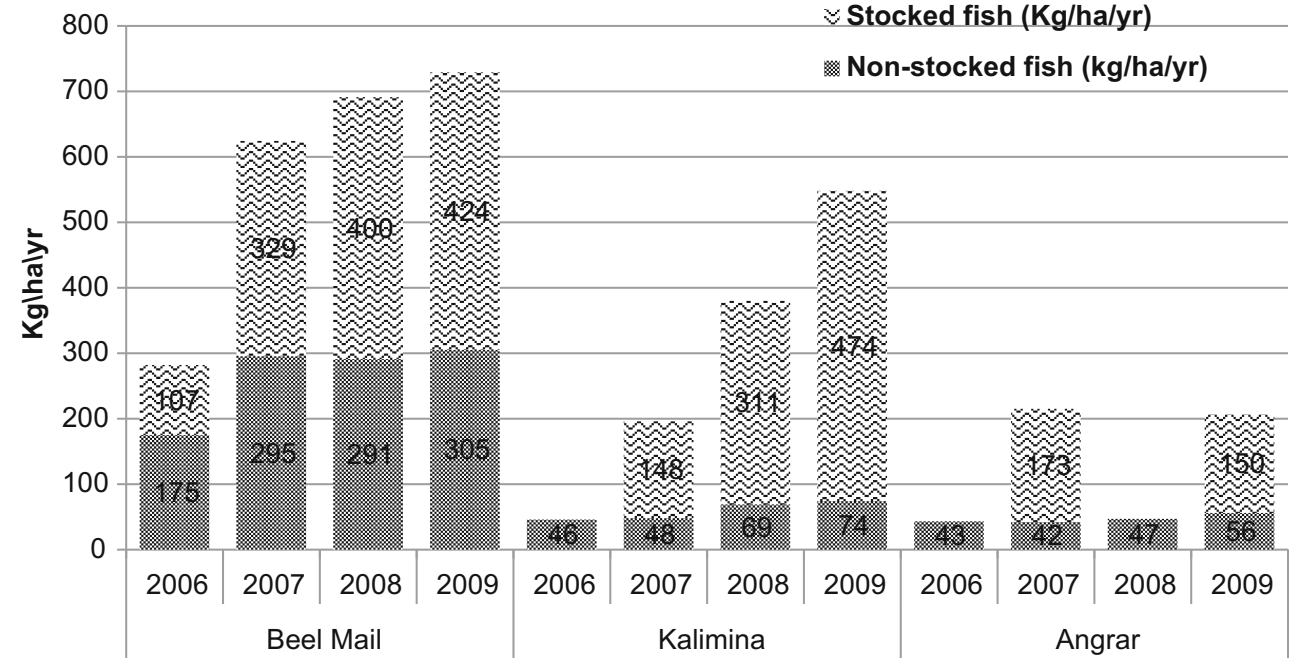

(private floodplain) were outside the project area and thus did not have a fish culture, as opposed to the three sites included in the project. So, a before-and-after analysis was only employed for the analysis of the impact of CBFC on fish production at floodplain level.

Among the three floodplains, the greatest increase in fish production occurred in the public floodplain of Beel Mail (from $282 \mathrm{Kg} / \mathrm{ha}$ in 2006 to $729 \mathrm{Kg} / \mathrm{ha}$ in 2009) when compared to the private floodplains of Kalmina and Angrar (Fig. 2). Here the comparable increases were from $46 \mathrm{~kg} / \mathrm{ha}$ to $548 \mathrm{~kg} / \mathrm{ha}$ in Kalmina, and from $43 \mathrm{~kg} / \mathrm{ha}$ to $206 \mathrm{~kg} / \mathrm{ha}$ in Angrar floodplains. From 2006 to 2009, the average fish production in the three sites included in the project area increased from $124 \mathrm{~kg} / \mathrm{ha}$ to $464 \mathrm{~kg} / \mathrm{ha}$, including stocked and nonstocked fish. The overall fish production in the project floodplains was $274 \%$ higher than the baseline fish production.

The presence of a connecting channel between the Beel Mail floodplains and the nearby river, where natural sanctuaries are established, also facilitated the entrance of non-stocked fish into the floodplains during the flooding period. The production of fish in Beel Mail after implementation of the project was significantly higher than the year before (2006), even though fish culture was initiated in the Beel under the community's own initiative in 2005.

In the floodplain at Kalmina Beel, total fish production reached $548 \mathrm{~kg} / \mathrm{ha}$ in 2009 , compared with the baseline fish yield of $46 \mathrm{~kg} / \mathrm{ha}$ in 2006. Similarly, fish yield per hectare increased to $206 \mathrm{~kg}$ in Angrar floodplain, compared with the baseline yield of $43 \mathrm{~kg} / \mathrm{ha}$. Stocking of fingerlings was not possible in Angrar floodplain during 2008 due to conflict among group members, but the problem was solved subsequently and community based fish culture was resumed in the following year. Before project implementation, the Kalmina and Angrar floodplains were completely open although they were private land, and no fisheries enhancement program had been launched. The surrounding community pond owners, fishermen and landless people, used to harvest fish in ditches or ponds The physical nature of the floodplain, larger size of fingerlings, facilities for allowing wild fish to enter the system from outside, techniques for multiple harvests, regulation of harvests and environmental factors contributed to the increased productivity of both stocked and non-stocked fish. These data indicate that the implementation of the technical approach was helpful in increasing fish production in the floodplains under community based fish culture.

Table 2 shows the cost and return analysis of the CBFC project areas. Since no cost and return data were collected by the project staff in the baseline survey, data on cost and return of CBFC are now only available for the three project sites included in our research for the period of 2007 to 2009. The ratio of net income to variable cost (BCR) was greater than 1 in Beel Mail and Kalmina floodplains for all the three study years; the ratios averaged 1.64 for Beel Mail and 1.17 for Kalmina. However, it was less than 1 during the study period in Angrar Beel, with an average ratio of 0.50. Overall, for the three floodplains, the ratio stood at 1.15 for the three years combined. The net income figures were also high for Beel Mail and Kalmina, ranging from 105 USD to 267 USD per hectare per year; averaging 183 USD for Beel Mail and 214 USD for Kalmina for the 2007-2009 period. On the other hand, the net income for Angrar for the 2007-2009 periods was only 45 USD per hectare per year.

\section{Distribution of benefit from community-based fish culture}

The share of net profit for fish production from the floodplains, agreed at the start of project activities, varied by the types of beneficiaries and across floodplains. Benefit sharing was decided and agreed upon by the beneficiaries and finally by the FMC. At the public floodplain (Beel Mail), the fishermen received a large share of the benefit, as they paid the least money for the floodplain. The fishermen in this floodplain 
Table 2 Cost and Return Analysis of CBFC (USD/ha/year)

\begin{tabular}{|c|c|c|c|c|c|c|c|c|c|c|c|c|c|}
\hline \multirow[t]{2}{*}{ Items } & \multicolumn{4}{|c|}{ Beel Mail } & \multicolumn{4}{|c|}{ Angrar } & \multicolumn{4}{|c|}{ Kalmina } & \multirow{2}{*}{$\begin{array}{l}\text { All floodplains } \\
\text { 2007-2009 }\end{array}$} \\
\hline & 2007 & 2008 & 2009 & 2007-2009 & 2007 & 2008 & 2009 & 2007-2009 & 2007 & 2008 & 2009 & $2007-2009$ & \\
\hline Input Costs & 75 & 114 & 145 & 112 & 87 & 86 & 93 & 90 & 161 & 186 & 203 & 183 & 128 \\
\hline Fixed costs & 19 & 14 & 36 & 23 & 36 & 34 & 22 & 29 & 73 & 73 & 86 & 77 & 43 \\
\hline Total Costs & 94 & 128 & 182 & 135 & 123 & 115 & 116 & 120 & 234 & 259 & 290 & 261 & 172 \\
\hline Total Income & 199 & 307 & 449 & 318 & 162 & 140 & 167 & 164 & 432 & 492 & 501 & 475 & 319 \\
\hline Net Income & 105 & 179 & 267 & 183 & 38 & 54 & 51 & 45 & 198 & 237 & 212 & 214 & 147 \\
\hline Net Income/ Variable Cost & 1.40 & 1.57 & 1.84 & 1.64 & 0.44 & 0.62 & 0.55 & 0.50 & 1.23 & 1.27 & 1.04 & 1.17 & 1.15 \\
\hline Net Income/ Total Cost & 1.12 & 1.40 & 1.47 & 1.36 & 0.31 & 0.46 & 0.44 & 0.38 & 0.85 & 0.92 & 0.73 & 0.82 & 0.86 \\
\hline
\end{tabular}

This research

also received considerable benefits by taking control of fish harvested from the floodplain. They received $50 \%$ of the value of the harvest of non-stocked fish and 10-15\% of the stocked fish. Furthermore, access of landless and seasonal fishermen from communities surrounding the floodplain using local gear was allowed throughout the season. In all project floodplains, the landless non-fishermen were allowed to harvest fish for their subsistence throughout the season. In the private floodplains (Kalmina and Angar) land owners and ditch owners received the major share of the benefits compared to other stakeholders; but fishermen did get $50 \%$ percent share of non-stocked fish and $10-15 \%$ of the stocked fish. The present study indicates that the involvement of all stakeholders ensured that property rights of secure access to fishing in the floodplain was retained, which contributed to increasing household incomes for up to 6 months of the year.

\section{Supplementary impact on crop production at floodplain level}

As indicated earlier, the boro rice crop was cultivated in project and control floodplains during the dry season (usually January to May). Aman rice (wet season rice) varieties that can survive a longer duration of inundation were cultivated in some areas on the periphery of the floodplains during the rainy season (June to December). Boro rice cultivation needs a total of 13-15 irrigation cycles and aman rice cultivation, which mainly depends on rain water, needs $1-2$ irrigation cycles for good harvests. The ditches constructed in the project sites were used as supplementary sources of surface water, ${ }^{5}$ and at least 4-5 irrigation cycles were saved for rice production.

Prior to project implementation, farmers used $26 \%$ and $74 \%$ of floodplain water and ground water, respectively, for irrigation purposes during the boro season. After project implementation, $43 \%$ of farmers used floodplain water to meet their irrigation needs, whereas $57 \%$ of farmers used ground

\footnotetext{
${ }^{5}$ Water levels in the project floodplains were maintained during the wetseason through the management of the outlets by using small concrete culverts)
}

water before. The use of floodplain water reduced water usage from ground water sources by $17 \%$. This result shows that CBFC provides an opportunity to use rainwater and minimize the use of expensive ground water, which reduces overall cost of rice cultivation. Use of floodplain water by beneficiaries increased from between $13 \%$ and $18 \%$ pre-project implementation to $31 \%$ post-implementation.

Use of floodplain water for supplementary irrigation in wet-season (aman) rice fields helped in increasing rice production. Rice production in dry season (boro) and wet-season (aman) seasons was significantly increased (Table 2). Due to implementation of the community based fish culture, rice production increased by $18.9 \%$ for boro and $28.90 \%$ for aman rice (Table 3 ).

\section{Effect on income at household level}

Given that detailed data on income was not collected in the baseline survey, a comparison of the income of households in project sites and control sites is presented in this section. The average fish income, non-fish income and total income of the fishermen, landless non-fishermen, and landowner's households in the project sites significantly increased as compared to households in the control sites (Table 4 and Table 5). We analyzed the income of CBFC project households and control households according to income source, based on the mean values of three years' income. ${ }^{6}$ Table 4 shows that households' fish income was higher for the households in the CBFC project than the controls as was overall household income during the project period (2007 to 2009).

In 2007, fish income for project beneficiaries increased to USD $211 / \mathrm{hh}$, which was about four times greater than the control group (USD 56/hh). The increased fish income for project households was almost the same in 2008 (USD 231/ hh) and 2009 (USD 277/hh); which was $175 \%$ and $274 \%$ higher than control households, respectively. Over the three

\footnotetext{
${ }^{6}$ We deflated the incomes for 2008 and 2009 using the 2007 consumer price index.
} 


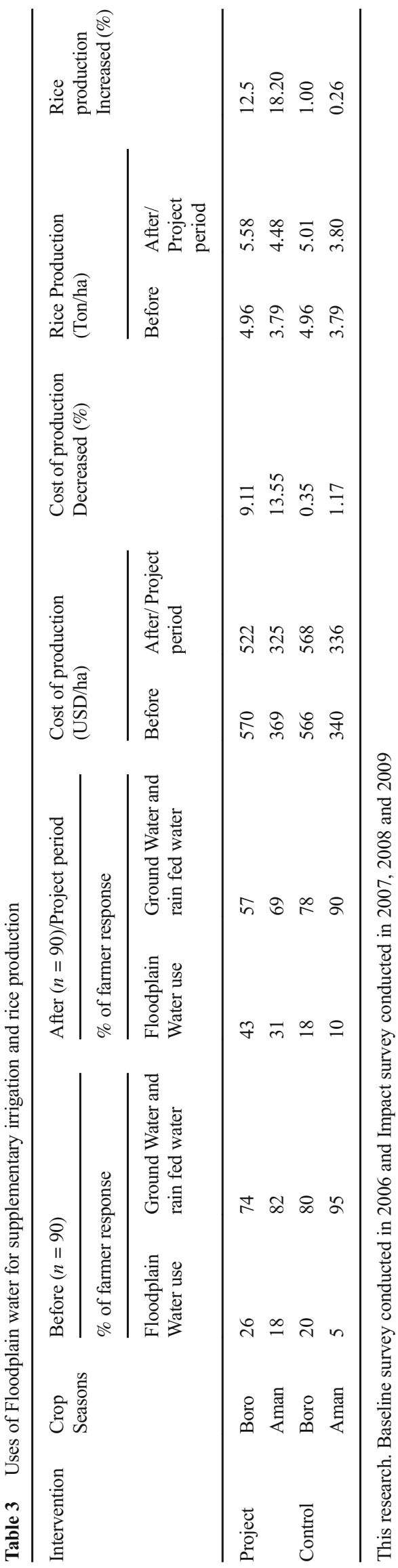

project years, the average fish income increased to USD 240/ hh for those included in the project compared with USD 71/hh for the control group. Fish income as percentages of total income for the project and control farmers were $22 \%$ and $8 \%$, respectively.

Table 6 displays the impact of various factors on income determined by the random effects model (Eq. 2). The model was estimated for three income types: fish income, non-fish income and total household income. The coefficients of the "participation in CBFC" variable reveal the effect of the CBFC system on various types of income, ceteris paribus. Project households significantly increased their fish income compared to the control (non-CBFC project) households. Fish income of the project households remained significantly higher than that of the control households for every year in the data sample. In addition, during 2009, the magnitude of increase in fish income exceeded that of the previous two years. This suggests that fish income increased significantly due to the introduction of the CBFC management system. There was no significant impact on non-fish income after project implementation. Furthermore, total household income increased to about USD 175 for those who participated in the program. Therefore, it can be concluded that the CBFC management system increased the overall household income in the floodplain areas.

\section{Employment effect}

Table 7 shows that fish culture activities generated employment in the floodplain areas. Before project implementation, floodplains were not properly utilized for fish culture. One site (Beel Mail) had some fish culture before the project started, but fish yield was low. Furthermore, data on labour use were not collected for the baseline year (2006). Our research is the first to measure employment opportunity in the project intervention sites.

As a direct result of project implementation, employment opportunities in the different fish culture activities were created. Fish culture in seasonal floodplains is an extensive method of fish production, characterized by low cost and high labour intensity. Community members willingly participated in the different fish culture activities. In every site, the landless nonfishermen and fishermen from surrounding floodplains were involved in fish culture activities as sources of labour. The setting of bana fencing, installed in different places throughout the floodplain, was performed by landless non-fishermen and fishermen. Two or three landless non-fishermen were engaged as guards for a period of 3 to 4 months. The Floodplain Management Committee (FMC) allowed the landless fishermen to catch fish in the floodplain. A large number of labourers was engaged in fishing at every site. Over the project period, partial harvest of fish was from mid-October and lasted to January, which allowed for longer periods of 
Table 4 Comparison of annual fish income from waterbody to the total income in project and control sites

\begin{tabular}{|c|c|c|c|c|}
\hline Source & 2007 & 2008 & 2009 & Average \\
\hline & Amount (USD/hh) & Amount (USD/hh) & Amount (USD/hh) & Amount (USD/hh) \\
\hline \multicolumn{5}{|l|}{ Project $(n=180)$} \\
\hline Fish income & 211 & 231 & 277 & 240 \\
\hline Non-fish income(other farm)* & 483 & 538 & 565 & 529 \\
\hline Non-farm Income** & 312 & 329 & 343 & 328 \\
\hline Total Income & 1006 & 1098 & 1185 & 1097 \\
\hline \multicolumn{5}{|l|}{ Control $(n=180)$} \\
\hline Fish income & 56 & 84 & 74 & 71 \\
\hline Non-fish income(other farm)* & 479 & 444 & 500 & 475 \\
\hline Non-farm Income** & 296 & 365 & 371 & 350 \\
\hline Total income & 849 & 893 & 945 & 896 \\
\hline \multicolumn{5}{|l|}{ Change } \\
\hline Fish income & 155 & 147 & 203 & 169 \\
\hline Non-fish income(other farm)* & 4 & 94 & 65 & 54 \\
\hline Non-farm Income** & 16 & -36 & -28 & -22 \\
\hline Total income & 157 & 205 & 240 & 201 \\
\hline
\end{tabular}

*Non-fish income includes other farm income like crop, livestock and poultry

**Non-farm income includes labour service, business

A water body includes the project floodplain and other sources, such as rivers

This research. Surveys conducted in 2007, 2008 and 2009

employment. From 2007 to 2009, 2495 labourers were engaged in fish culture activities; indicating that there is a large requirement for labour involvement. The average numbers of labourers per hectare engaged in culture activities were 19, 19, and 34 in 2007, 2008, and 2009, respectively.

The adoption of fish culture practices has the potential to increase the total labour requirement to some extent (Ahmed et al. 1996; Dey 2000; Ahmed and Lorica 2002). Another direct way in which poor floodplain communities stand to benefit from adoption of fish culture is by improving returns to labour in terms of physical and monetary units. This study shows that the performance of the CBFC project in terms of labour productivity and returns to labour improved significantly after project implementation; and it was significantly higher in post-implementation periods. Labour productivity was highest in $2008(20 \mathrm{~kg}$ man-days $^{-1}$ ), and lowest in 2009 (14 Kg man-days $\left.{ }^{-1}\right)$. The return to labour was highest in 2009 (USD 6 labourer ha ${ }^{-1}$ ) and lowest in 2008 (USD 2 labourer ha ${ }^{-1}$ ). Another important impact of fish culture in floodplains on employment was a series of backward linkage effects such as hatcheries, nurseries, seed production, feed, and input deliveries; there were also forward linkage effects, such as post-harvest handling, processing, and marketing of fish (Jahan et al. 2010; Lewis et al. 1996).

\section{Effect on consumption at household level}

According to FAO, food security is the physical and economic access to the basic food needed by all human beings; and it implies availability, stability, and access to this food (1996). Fish play a vital role in providing food security and good

Table 5 Share of fish income (USD/hh/year) from the floodplain to the total income in project and control sites

\begin{tabular}{|c|c|c|c|c|c|c|c|c|}
\hline \multirow[t]{2}{*}{ Sample Category } & \multicolumn{3}{|c|}{ Project $n=180$} & \multicolumn{3}{|c|}{ Control $n=180$} & \multicolumn{2}{|l|}{ Changes } \\
\hline & Fish income & Total Income & $\%$ of income & Fish income & Total Income & $\%$ of income & Fish income & Total Income \\
\hline Fisher & 224 & 698 & 32 & 120 & 538 & 22 & 103 & 160 \\
\hline Landless non-fisher & 185 & 705 & 26 & 83 & 533 & 15 & 102 & 172 \\
\hline Landowner & 311 & 1889 & 16 & 11 & 1617 & 1 & 300 & 271 \\
\hline All (average) & 240 & 1097 & 22 & 71 & 896 & 8 & 169 & 201 \\
\hline
\end{tabular}

This research. Surveys conducted in 2007, 2008 and 2009 
Table 6 Impact on income using random effects model (with common support)

\begin{tabular}{|c|c|c|c|}
\hline Variable & Impact on fish income & $\begin{array}{l}\text { Impact on } \\
\text { non-fish income }\end{array}$ & $\begin{array}{l}\text { Impact on total } \\
\text { household income }\end{array}$ \\
\hline Participation in CBFC & $154.00 *(9.71)$ & $21.12(18.84)$ & $174.93 *(319.38)$ \\
\hline Age of the household head & $42.61(30.75)$ & $-99.80(129.16)$ & $-57.35(131.50)$ \\
\hline Education of the household head & $-147.13 * * *(83.50)$ & $2572.54 *(466.17)$ & $2425.01 *(480.23)$ \\
\hline Religion & $-1888.23 * *(928.65)$ & $644.43 *(2678.73)$ & $4523.11(2932.23)$ \\
\hline Family size & $573.82 * *(249.35)$ & $2866.44 *(1384.02)$ & $3448.95 * * *(1442.53)$ \\
\hline Pond area & $12.20 * *(5.51)$ & $275.93 *(68.89)$ & $850.86^{* *}(282.53)$ \\
\hline Rice land in the floodplain & $15.32 * * *(9.04)$ & $341.11 *(53.06)$ & $356.35 *(55.89)$ \\
\hline Ditch area & $21.39 *(7.86)$ & $231.43 *(26.88)$ & $252.94 *(27.29)$ \\
\hline Number of fishing boats & $45.54(517.72)$ & $-2649.18(2487.68)$ & $-2559.77(2615.83)$ \\
\hline Year 2008 & $23.57 *(4.63)$ & $40.82 *(21.01)$ & $64.30 * *(21.66)$ \\
\hline Year 2009 & $41.695 *(4.984)$ & $101.124 *(24.723)$ & $142.823 *(25.308)$ \\
\hline Constant & $1814.19(1337.90)$ & $10,587.08(6564.93)$ & $12,404.39(6816.53)$ \\
\hline Wald $\chi^{2}(12)$ & 475.78 & 452.80 & 550.12 \\
\hline Prob. $>x^{2}$ & 0.000 & 0.000 & 0.000 \\
\hline $\mathrm{R} 2$ & 0.484 & 0.513 & 0.518 \\
\hline Number of observations & 1080 & 1080 & 1080 \\
\hline
\end{tabular}

$*$, **, and *** indicate significance at the $10 \%, 5 \%$, and $1 \%$ level, respectively. Figures in parentheses are robust standard errors. nutrition to billons of people in both developed and developing countries (Béné et al. 2015; Toufique and Belton 2014). Several studies have investigated food security in Bangladesh in terms of per capita food availability, pattern of household food consumption and causes of food insecurity (Begum 2002; RDRS 2005; Mishra and Hossain 2005). Our study provides descriptive statistics of food security with food security and nutritional intake having improved significantly among the project beneficiaries.

A before-and-after analysis with intervention and without intervention design was followed for analyzing the impact of $\mathrm{CBFC}$ on food security and fish consumption. The results show that the per capita fish consumption of project households increased from $1.26 \mathrm{~kg} \mathrm{capita}^{-1}$ month $^{-1}$ in the baseline year (2006) to $2.31 \mathrm{~kg} \mathrm{capita}^{-1} \mathrm{month}^{-1}$ in 2009 (Table 8). Over the course of the project the per capita fish consumption increased significantly compared to the baseline year (2006); increases of $34 \%, 58 \%$ and $84 \%$ for 2007, 2008, and 2009, respectively. During the same period, the per capita monthly consumption of fish in control households increased from $1.23 \mathrm{~kg}$ capita $^{-1}$ month $^{-1}$ in the baseline year, to $1.63 \mathrm{~kg}$ capita $^{-1}$ month $^{-1}$ in $2009 .^{7}$

The average monthly fish consumption, considering all species, was higher for project beneficiaries $(2.00 \mathrm{~kg} /$ person) than for their control counterparts

\footnotetext{
${ }^{7}$ National average of per capita fish consumption is about 0.95 capita $^{-1}$ month $^{-1}$ (Bangladesh Economic Review 2005). It is assumed that the actual per capita fish consumption in Bangladesh is higher than the national average reported in official databases (FAO 1999, 2002; Welcome 2001; Ahmed et al. 1996; Dey et al. 2005b).
}

(1.55 kg/person) during the 2007 to 2009 period. Due to implementation of the CBFC project, the average per capita fish consumption per month in project areas increased by $58 \%$ in comparison to the baseline year; the corresponding increase was $26 \%$ in control sites. This shows that the growth rate of monthly fish consumption was higher for project beneficiaries.

The per capita fish consumption for all groups, both the project beneficiaries and control group, increased over the years; however, the rate of that increase was not same for all years (Table 9). Among the project beneficiaries, landless non-fishermen went through the fastest annual growth in per capita fish consumption during 2006 to 2009 at $33.22 \%$, followed by fishermen $(27.11 \%)$, and landowners $(19.01 \%)$. Overall, the per capita fish consumption for the project beneficiaries increased from $1.26 \mathrm{~kg}$ per capita per month to $2.31 \mathrm{~kg}$ per capita per month, an annual increase of $24.75 \%$. On the other hand, the control group witnessed an average annual increase of only $10.34 \%$ (from $1.23 \mathrm{~kg} /$ capita/month to $1.63 \mathrm{~kg}$ / capita/month) over the project years. The results signify that the control group saw less growth in fish consumption compared to project beneficiaries.

The differences in fish consumption between project beneficiaries and control group members over the years are further highlighted by the last three columns of Table 9. The difference in fish consumption for all the groups increased over the years and overall. The difference between project beneficiaries and the control group was $0.20 \mathrm{~kg}$ per capita per month in 2007 , which went up to $0.46 \mathrm{~kg}$ per capita per 
Table 7 Employment generated in the Community Based Fish Culture project from 2007 to 2009

\begin{tabular}{|c|c|c|c|c|c|c|c|}
\hline \multirow[t]{2}{*}{ Year } & \multicolumn{4}{|c|}{ Employment generated in three floodplain (Person-days) } & \multirow[t]{2}{*}{ Person-days/ha } & \multirow{2}{*}{$\begin{array}{l}\text { Labour productivity } \\
\text { (kg/ha/labourer) }\end{array}$} & \multirow{2}{*}{$\begin{array}{l}\text { Return to labour } \\
\text { (USD/ha/labourer) }\end{array}$} \\
\hline & Setting of Bana Fencing & Guarding & Fish Harvesting & Total & & & \\
\hline 2007 & 276 & 630 & 1055 & 1961 & 19 & 18 & 5 \\
\hline 2008 & 271 & 445 & 1222 & 1938 & 19 & 20 & 2 \\
\hline 2009 & 252 & 666 & 2668 & 3586 & 34 & 14 & 6 \\
\hline All (Average) & 266 & 580 & 1648 & 2495 & 24 & 16 & 4 \\
\hline
\end{tabular}

This research

month in 2008 , and then further upwards to $0.67 \mathrm{~kg}$ per capita per month in 2009.

Figure 3 presents the trends in fish consumption in both project and control households from 2007 to 2009. The monthly fish consumption of project beneficiaries varied in different months (Fig. 3). Due to project implementation, fish availability was increased in the project area during the period from July to December. Fish consumption of the project beneficiaries increased when compared to control farmers during the months of July to December. This was possible only due to changing production technology from capture to culture fisheries. Approximately $68 \%$ to $75 \%$ of the total fish consumption requirements of the project beneficiaries were fulfilled by fish culture in the floodplains in the months of July through December.

The supplies of fish from the implementation sites had significant impact on fish consumption at the community level and also the local market. The results of the study show that about $20-30 \%$ of non-stocked fish were sold at farm gate to the community people as well as to local middlemen or paikers, who had the opportunity to purchase fish at a cheaper price. The remainder, i.e. 70-80\%, was sold to adjacent local markets on a wholesale basis. It may therefore be concluded that the availability of fish at the community level will increasingly fulfil the consumption needs of the community as fish production in the floodplains increases.

\section{Prospects and challenges of community-based fish culture in Bangladesh}

After successful implementation of the "Community-based Fish Culture in Seasonal Floodplains and Irrigation System" project in Bangladesh, many communities neighboring the trial and demonstration sites have copied the CBFC system to suit their situation. Communities in two of the three project sites (Beel Mail and Kalmina) are still continuing CBFC, and all project participants (landowner, landless, and fishers) are obtaining the benefits. The Department of Fisheries of the Government of Bangladesh and several non-governmental organizations have selected CBFC as part of their development programs. WorldFish has recently completed a follow-up CBFC projects in six sites. These projects show that the CBFC system provides benefit to all concerned stakeholders within the communities (including landowners, landless nonfishers, and fishers).

Scaling-up of CBFC technology requires suitable topographical locations and appropriate institutional arrangements. It is necessary that natural topography (such as saucer-shaped natural depressions, or existing artificially elevated lands through homesteads, dams, etc.) enclose the area on multiple sides to allow fencing off at low cost. Also, the prevailing social conditions should be such that all stakeholders of a waterbody can be involved in shared management arrangements,

Table 8 Trend in per capita fish consumption $\left(\mathrm{Kg} \mathrm{Capita}^{-1} \mathrm{month}^{-1}\right)$ among project and control households

\begin{tabular}{|c|c|c|c|c|}
\hline \multirow[t]{2}{*}{ Year } & \multicolumn{2}{|l|}{ Project households } & \multicolumn{2}{|l|}{ Control households } \\
\hline & Fish Consumption & $\begin{array}{l}\text { Percentage increased } \\
\text { compare to baseline }\end{array}$ & Fish Consumption & $\begin{array}{l}\text { Percentage increased } \\
\text { compare to baseline }\end{array}$ \\
\hline 2006 (Baseline) & $1.26 \pm 0.57$ & - & $1.23 \pm 0.5$ & - \\
\hline 2007 & $1.69 \pm 0.80$ & 34 & $1.48 \pm 0.48$ & 20 \\
\hline 2008 & $2.00 \pm 0.53$ & 58 & $1.54 \pm 0.38$ & 25 \\
\hline 2009 & $2.31 \pm 0.47$ & 84 & $1.63 \pm 0.42$ & 33 \\
\hline 2007-2009 (Average) & $2.00 \pm 0.61$ & 58 & $1.55 \pm 0.42$ & 26 \\
\hline
\end{tabular}

This research. Baseline survey conducted in 2006 and monthly consumption surveys conducted in 2007, 2008 and 2009. 


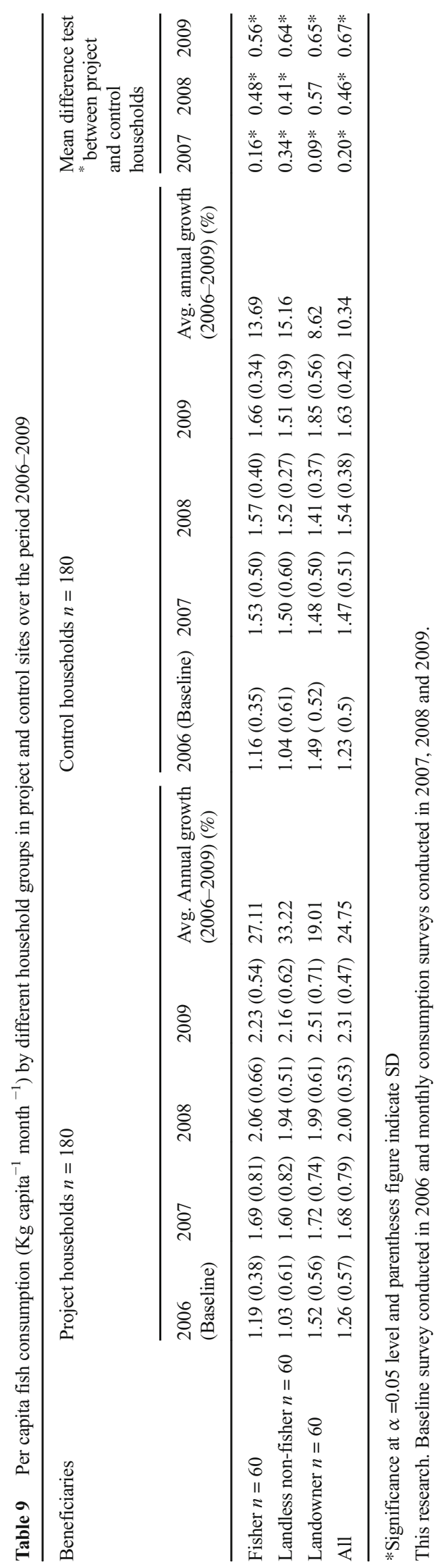

including landowners, leaseholders, landless fishers (who may have customary rights to fish in the flooded waterbody but be restricted from access during the dry season). Communities in the Angrar project site did not continue mainly because of the changes in topographical condition and some conflicts among group members; a new embankment has been constructed, which made the area not so suitable for fish culture during the rainy season.

Farmers' groups will have to negotiate and agree on cooperative sharing arrangements, rules, technical details and schedules for operation. This may be influenced by other existing agreements and ongoing conflicts. The linkages with formal and informal institutions and organizations within the villages and outside of the villages are, therefore, critical for the sustainability of the organizations, as well as for successful adaption of community-based fish culture in floodplains during the rainy season.

\section{Conclusions}

The impacts of community based fish culture in seasonal floodplains have been diverse across, and within, floodplains. The results presented in this paper clearly show that there is potential to introduce fish culture systems in the place of capture fishery activity in floodplain areas. This can increase fish production, supply vital nutrition to poor households and improve the overall welfare of the low-income and resource-poor households. Introduction of this approach has had a significant and positive impact on income, employment, and household nutrition for adopters. This paper also demonstrates that income of labourers and fish consumption were significantly higher among the project beneficiary households than control households. Since there were no major differences between project beneficiaries and controls in terms of socio-economic parameters, such as household size, floodplain size, experience in collective action, and there were no other projects that took place during this time period, it can be concluded that the achievement of all benefits, in terms of fish production, consumption, employment generation, and overall food security during the project period was mainly due to project implementation.

The innovations of the community-based approach to fish culture in floodplains have been widely used in Bangladesh by different institutions (including the Department of Fisheries, Government of Bangladesh), as well as in other countries of Asia. The CBFC system has huge potential benefits, as a large number of people depend on the 2.8 million hectares of floodplains for their livelihoods. Improvements in floodplain productivity and ecosystem services are important, as are addressing issues of governance for how to manage floodplains 
Fig. 3 Seasonality of fish consumption (2007-2009) in project and control areas

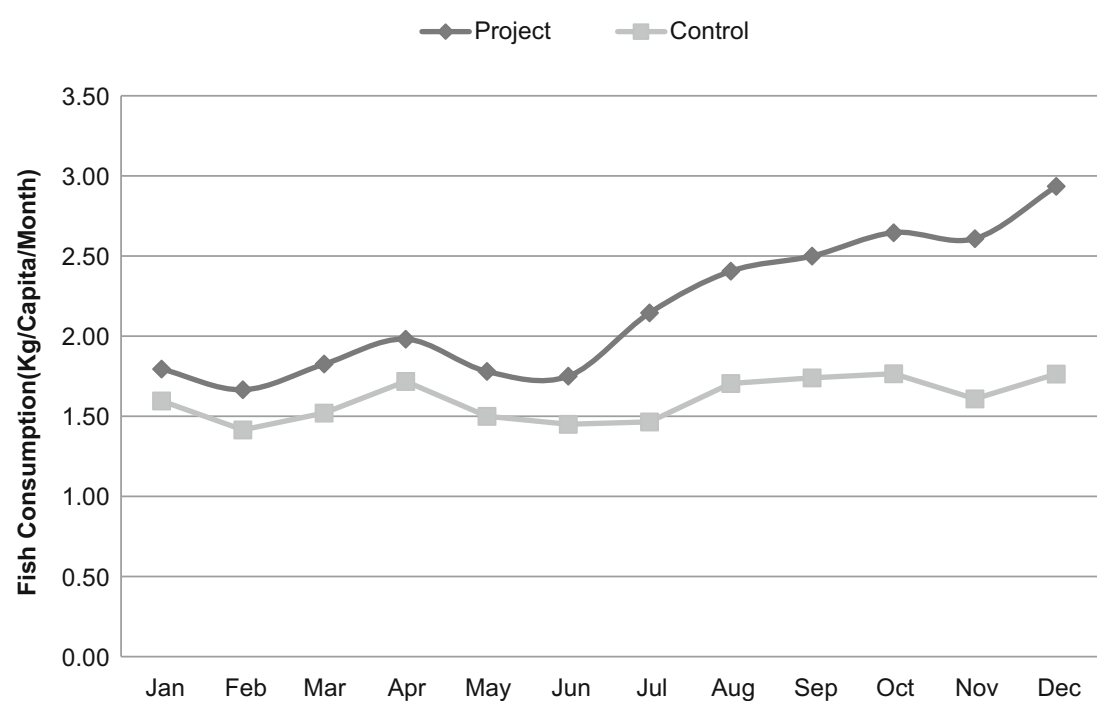

and make the system work. The promotion of community based fish culture in seasonal floodplains may thus be a useful tool to bring about dramatic positive changes in trends of overall productivity and livelihood gains for poor people in Bangladesh.

\section{Compliance with ethical standards}

Conflict of interest The authors declared that they have no conflict of interest.

Open Access This article is distributed under the terms of the Creative Commons Attribution 4.0 International License (http:// creativecommons.org/licenses/by/4.0/), which permits unrestricted use, distribution, and reproduction in any medium, provided you give appropriate credit to the original author(s) and the source, provide a link to the Creative Commons license, and indicate if changes were made.

\section{References}

Adato, M., \& Meinzen-Dick, R. (2007). Agriculture research, livelihood, and poverty studies of economic and social impact in six countries, international food policy research institute. Baltimore: The John Hopkins University Press.

Ahmed, M., \& Lorica, M. H. (2002). Improving developing country food security through aquaculture development lessons from Asia. Food Policy, 27, 125-141.

Ahmed, M. M., Tana, T. S., \& Thouk, N. (1996). Sustaining the gifts of the Mekong: the future of freshwater capture fisheries in Cambodia. Watershed, 1(3), 33-38.

Bangladesh Economic Review (2005). Bangladesh economic review. Economic Advisers Wing, Finance Division, Ministry of Finance, Dhaka.

Bangladesh Economic Review (2013). Bangladesh economic review. Economic Advisers Wing, Finance Division, Ministry of Finance, Dhaka.

Begum, S. (2002). Proceedings of the APO seminar on role of rural women in food security in Asia and the Pacific. Held in Thailand from 21 to 25 August 2000. Asian Productivity Organization, Tokyo, Japan.

Béné, C., Barange, M., Subasinghe, R., Pinstrup-Anderson, P., Merino, G., Hemre, G., \& Williams, M. (2015). Feeding 9 billion by 2050putting fish back on the menu. Food Security, 7(2), 261-274.

Dey, M. M. (2000). Analysis of demand of fish in Bangladesh. Aquaculture Economics and Management, 4, 63-82.

Dey, M. M., \& Prein, M. (2005). Increased income from seasonally flooded rice fields through community based fish culture in Bangladesh and Vietnam. Plant production science, 8(3), 349-353.

Dey, M. M., \& Prein, M. (2006). Community-based fish culture in seasonal floodplains. Naga, 29(1 \& 2), 21-27.

Dey, M. M., Prein, M., Haque, A. B. M. M., Sultana, P., Dan, N. C., \& Hao, N. V. (2005a). Economic feasibility of community-based fish culture in seasonally flooded rice fields in Bangladesh and Vietnam. Aquaculture Economics and Management, 9(1 \& 2), 65-88.

Dey, M. M., Rab, M. A., Paraguas, J. P., Piumsombun, S., Bhatta, R., Alam, M. F., \& Ahmed, M. (2005b). Fish consumption and food security: a disaggregated analysis by types of fish and classes of consumers in selected Asia countries. Aquaculture Economics and Management, 9, 89-111.

Dey, M. M., Kambewa, P., Prein, M., Jamu, D., Paraguas, F. J., Briones, R., \& Pemsl, D. E. (2007). Impact of the development and dissemination of integrated aquaculture-agriculture (IAA) technologies in Malawi. In H. Waibel \& D. Zilberman (Eds.), International research on natural resources management: advances in impact assessment (pp. 118-146). Oxfordshire: CAB International.

DoF (Department of Fisheries). 2013. Fish fortnight compendium 2013. Department of Fisheries, Ministry of Fisheries and Livestock, Dhaka, Bangladesh. 120 p.

Edwards, P. (1999). Aquaculture and poverty: past, present and future prospects of impact. A discussion paper prepared for the Fifth Fisheries Development Donor Consultation, Rome.

FAO, (1996). Implication of economic policy for food security: a training manual, Rome

FAO (1999). The state of world fisheries and aquaculture. Rome: FAO Fisheries Department.

FAO (2002). The state of world fisheries and aquaculture. Rome: FAO Fisheries Department.

FAO (2014). The state of world fisheries and aquaculture. Rome: FAO Fisheries Department.

FRSS (2015). Fisheries statistical report of Bangladesh, fisheries resources survey system (FRSS) (Vol. 30, p. 52). Bangladesh: Department of Fisheries. 
Grafton, R. Q., Williams, J., \& Jiang, Q. (2015). Food and water gaps to 2050: preliminary results from the global food and water system (GFWS) platform. Food Security, 7(2), 209-220.

Huang, F., Liu, Z., Ridoutt, B. G., Huang, J., \& Li, B. (2015). China's water for food under growing water scarcity. Food Security, 7(5), 933-949.

Jahan, K. M., Ahmed, M., \& Belton, B. (2010). The impacts of aquaculture development on food security: lessons from Bangladesh. Aquaculture Research, 41(4), 481-495.

Lewis D.J., Gregory R. \& Wood G.D. (1996). Trading the silver seed: local knowledge and market mortalities in aquaculture development. Intermediate technology publications and university press limited, Dhaka.

Mishra, U. and Hossain, S.A.K. (2005). Current food security and challenges: Achieving 2015 MDG hunger milepost. Food security in Bangladesh. Paper presented in the national workshop (pp.01-06), October 19-20, Dhaka.

Nagabhatla, N., Beveridge, M., Haque, A. B. M. M., Sophie NguyenKhoa, S., \& Brakel, M. V. (2012). Multiple water use as an approach for increased basin productivity and improved adaptation: a case study from Bangladesh. International Journal of River Basin Management, 10(1), 121-136.

Rahman, A. K., Giffin, K., \& Riskin, C. (1999). Income distribution in urban China during the period of economic reform and globalization. The American Economic Review, 89(2), 296-300.

Rahman, M. F., Barman, B. K., Ahmed, M. K., and Dewan, S. (2010a). Technical issues on management of seasonal floodplains under community-based fish culture in Bangladesh. World fish center, Bangladesh. Working Papers, World Fish

RDRS. (2005). A report of survey on food security and hunger in Bangladesh. ISBN 984-32-2562-7

Toufique, K. A., \& Belton, B. (2014). Is Aquaculture Pro-Poor? Empirical Evidence of Impacts on Fish Consumption in Bangladesh. World Development, 64, 609-620.

Toufique, K. A., \& Gregory, R. (2008). Common waters and private lands: distributional impacts of floodplain aquaculture in Bangladesh. Food Policy, 33, 587-594.

Welcome, R. L. (2001). Inland fisheries: ecology and management. Oxford: Fishing New Books, Blackwell Science.

Wichelns, D. (2015). Water productivity and food security: considering more carefully the farm-level perspective. Food Security, 7(2), 247 260

World Fish Center. (2005). Project proposal: community based fish culture in irrigation systems and seasonal floodplains: CGIAR challenge program on water and food, world fish center, Penang; Malaysia. City, pp. 2-19.

World Fish Center (2007). Floodplain aquaculture. Booklet no.8. The World Fish Center, Bangladesh and South Asia Office, Dhaka 12 p.

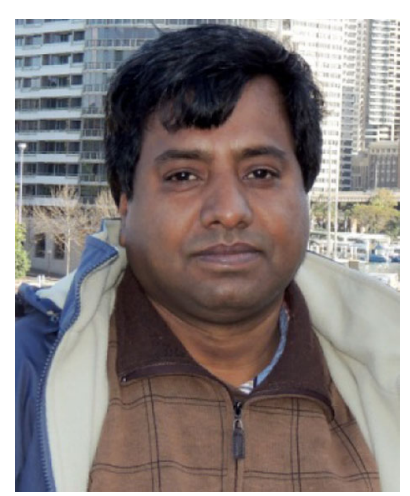

A.B.M. Mahfuzul Haque is a Ph.D. candidate at Wageningen University in the Netherlands. His $\mathrm{Ph} . \mathrm{D}$. research identifies institutional arrangements and their influence on power relations in the management of community based fisheries. His research aims to determine the impact of Community-based Fish Culture in Seasonal Floodplains and Irrigation Systems in Bangladesh on communities and households in order to provide data for developing policy to better utilize fish resources and improve fish-based livelihoods of the people living in and around the floodplains of Bangladesh. Eleven of his research papers are published in international and national journals. Mr. Haque is simultaneously working as a Monitoring \& Evaluation Specialist at the World Fish Bangladesh and South Asia office.

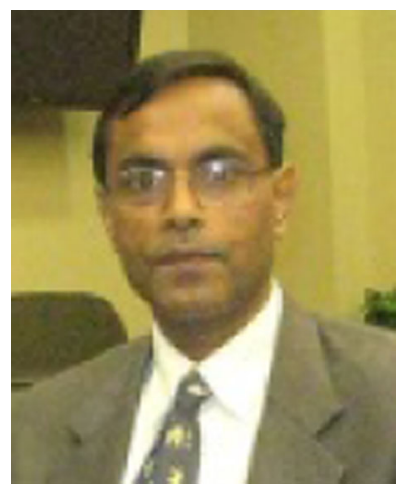

Madan M. Dey is a Full Professor (Ag. Econ.l Agribusiness) and Chair of the Department of Agriculture, Texas State University, USA. A $\mathrm{Ph}$. D in Agricultural Economics, he has more than 27 years of post $\mathrm{Ph} . \mathrm{D}$. experience in research, teaching, and governance in a variety of agricultural and natural resource contexts. He has published widely in several fields of agricultural/natural resource economics with more than 130 journal articles and book chapters. He received the Chancellor's "Distinguished Research, Scholarship, and Creative Activity Award" from UAPB in 2014. He has held posts in the United States, Malaysia, the Philippines and Bangladesh, and led research and development projects in more than 20 other countries of Asia, Africa and the Pacific. 